\title{
Identification and Isolation of Actin from Neurospora crassa
}

\author{
By LEN SIKORA AND GEORGE A. MARZLUF* \\ Department of Biochemistry, Ohio State University, Columbus, Ohio 43210, U.S.A.
}

(Received 22 April 1981)

\begin{abstract}
Crude cell extracts of Neurospora crassa contained an abundant protein that was identified as actin by a number of criteria. The protein, either in cell extracts or in pure form, co-migrated with rabbit skeletal muscle actin in polyacrylamide gels. The $N$. crassa actin was purified by DEAE-cellulose and DNAase I-Sepharose chromatography and had the expected property of inhibiting DNAase I activity. Although $N$. crassa actin could polymerize and depolymerize, purification based entirely on this characteristic was ineffective. The actin was susceptible to proteolytic degradation, and under certain conditions, a breakdown product of defined size was observed.
\end{abstract}

\section{INTRODUCTION}

Muscle cell actin has been the focus of numerous studies due to its involvement in the contractile apparatus. Actin is also a major protein in many non-muscle tissues and cell types of eukaryotic organisms (Korn, 1978; Pollard \& Weihing, 1974). In non-muscle cells actin is presumed to play a role in the functioning of the cytoskeleton in addition to participating in a number of cellular contractile processes. Non-muscle actins have many features in common and share certain biochemical properties with skeletal muscle actin. These properties include amino acid composition, molecular weight, the ability to form F-actin and to activate $\mathrm{Mg}^{2+}$-dependent myosin ATPase activity and the ability to inhibit deoxyribonuclease I (DNAase I). Purification procedures based upon these biochemical characteristics have facilitated the isolation of actin from several lower eukaryotic organisms, most notably Dictyostelium, Physarum and Saccharomyces (Hatano \& Oosawa, 1966; Henney \& Izadpanah, 1979; Kotelliansky et al., 1979; Uyemura et al., 1978).

In Dictyostelium discoideum, actin is an abundant protein and it is developmentally regulated in differentiating cells (Alton \& Lodish, 1977; Margolskee \& Lodish, 1980; Spudich, 1974). Recombinant DNA techniques have indicated that this organism possesses multiple actin genes as well as different size classes of actin mRNA (Bender et al., 1978; Kindle \& Firtel, 1978; McKeown et al., 1978).

Allen \& Sussman (1978) demonstrated by electron microscopy that crude Neurospora crassa extracts display a characteristic 'arrowhead' configuration after incubation with heavy meromyosin, suggesting the presence of actin. Here, we present biochemical data which indicates that $N$. crassa cells possess a protein with properties characteristic of actin.

\section{METHODS}

Organism and growth conditions. Wild-type Neurospora crassa strain 74 OR $231 \mathrm{~A}$ was obtained from the Fungal Genetics Stock Center, Arcata, Calif., U.S.A. Cultures were grown for 18-20 h in Vogel's Medium N (Vogel, 1956) supplemented with $1.5 \%(w / v)$ sucrose, and then harvested and washed with distilled water. The mycelium was either extracted with acetone (Munkres, 1962) or used directly for actin isolation.

Cell extract preparation. An acetone powder $(10 \mathrm{~g})$ of $N$. crassa mycelium was extracted as described by Spudich \& Watt (1971) except all solutions contained 1 mM-phenylmethylsulphonyl fluoride (PMSF) and 
$1 \mathrm{~mm}$-benzamidine. Cells $(100 \mathrm{~g})$ used directly for actin isolation by DEAE-cellulose chromatography were resuspended in $100 \mathrm{ml}$ of cold Tris buffer $\mathrm{pH} 8$ containing $5 \mathrm{mM}$-2-mercaptoethanol, $5 \mathrm{~mm}$-sodium pyrophosphate, $1 \mathrm{mM}$-PMSF, $1 \mathrm{~mm}$-benzamidine, $1 \mathrm{~mm}$-EDTA, $0.2 \mathrm{~mm}-\mathrm{KCl}$. The cells were disrupted in a Braun homogenizer with glass beads and the slurry was centrifuged at $15000 \mathrm{~g}$ for $0.5 \mathrm{~h}$ at $4{ }^{\circ} \mathrm{C}$. The supernatant fluid was brought to $2 \mathrm{mM}$-PMSF and $2 \mathrm{mM}$-benzamidine and centrifuged at $100000 \mathrm{~g}$ for $1.5 \mathrm{~h}$ at $4^{\circ} \mathrm{C}$.

DEAE-cellulose chromatography. The column $(35 \times 2 \mathrm{~cm})$ of DEAE-cellulose (Whatman DE-52) was equilibrated with $10 \mathrm{~mm}$-triethanolamine, $5 \mathrm{mM}$-sodium pyrophosphate, $20 \mathrm{mM}-\mathrm{KCl}, 50 \mu \mathrm{M}$-ATP, pH 8 (Henney \& Izadpanah, 1979); all procedures were carried out at $4{ }^{\circ} \mathrm{C}$. An equal volume of $10 \mathrm{~mm}$-triethanolamine, 1 mM-2-mercaptoethanol, $1 \mathrm{mM}$-PMSF, $1 \mathrm{mM}$-benzamidine, $50 \mu \mathrm{M}-\mathrm{MgCl}_{2}, \mathrm{pH} 8$ was added to the cell extract prior to its application to the DEAE-cellulose column. After the sample was applied, the column was washed with 120 $\mathrm{ml} 10 \mathrm{~mm}$-triethanolamine, $5 \mathrm{~mm}$-sodium pyrophosphate, $20 \mathrm{mM}-\mathrm{KCl}, 50 \mu \mathrm{M}-\mathrm{MgCl}_{2}$, $\mathrm{pH} 8$. The column was eluted with a 11 linear gradient of $0.02-1.0 \mathrm{M}-\mathrm{KCl}$ in the starting buffer. The flow rate was maintained at $50 \mathrm{ml}$ $\mathrm{h}^{-1}$ and fractions were collected and monitored at $290 \mathrm{~nm}$. Fractions that inhibited DNAase I activity (see below) were pooled and applied to a DNAase I-Sepharose affinity column.

DNAase I-Sepharose chromatography. DNAase I-Sepharose was prepared essentially according to Dhermy et al. (1978). CNBr-activated Sepharose 4B (6 g; Pharmacia) was incubated with $40 \mathrm{mg}$ DNAase I dissolved in $30 \mathrm{ml} 0.1 \mathrm{M}-\mathrm{NaHCO}_{3}, 0.5 \mathrm{M}-\mathrm{NaCl}$ and incubated at room temperature for $2 \mathrm{~h}$. The DNAase I column was washed twice with $0.1 \mathrm{M}-\mathrm{NaHCO}_{3}, 0.5 \mathrm{M}-\mathrm{NaCl}$ and then treated with $1 \mathrm{M}$-ethanolamine, $\mathrm{pH} 8$ for $2 \mathrm{~h}$. Following washes with $0.1 \mathrm{M}$-sodium acetate, $1 \mathrm{M}-\mathrm{NaCl}, \mathrm{pH} 4$ and $0.1 \mathrm{M}$-sodium borate, $1 \mathrm{M}-\mathrm{NaCl}, \mathrm{pH} 8$, the DNAase I-Sepharose was packed into a column $(1.5 \times 10 \mathrm{~cm})$. The column was washed with $200 \mathrm{ml} 0.01 \mathrm{M}-\mathrm{Tris}$, $0.001 \mathrm{M}-\mathrm{CaCl}_{2}, \mathrm{pH} 7.5$ and operated at $4{ }^{\circ} \mathrm{C}$. Before fractions from the DEAE-cellulose column were applied to this DNAase I affinity column, they were mixed with an equal volume of buffer $\mathrm{A}$ [0.5 $\mathrm{M}$-sodium acetate, 1 $\mathrm{mM}-\mathrm{CaCl}_{2}, 15 \%(\mathrm{v} / \mathrm{v})$ glycerol, $\left.\mathrm{pH} 6 \cdot 5\right]$. After application of the sample, the DNAase I column was washed with buffer A $(60 \mathrm{ml})$ until the $A_{280}$ of the eluate was reduced to the background reading. The column was then eluted with $32 \mathrm{ml}$ buffer A containing $0.75 \mathrm{M}$-guanidinium chloride $(\mathrm{GuHCl})$, followed by $40 \mathrm{ml}$ buffer A containing $3 \mathrm{M}-\mathrm{GuHCl}$. The fractions eluted with $\mathrm{GuHCl}$ were pooled and dialysed for $24 \mathrm{~h}$ at $4{ }^{\circ} \mathrm{C}$ against distilled water containing $1 \mathrm{mM}$-PMSF and $1 \mathrm{~mm}$-benzamidine. Following dialysis, the sample was lyophilized.

DNAase I inhibition assay. Two methods were used to assay for DNAase I inhibition by the $N$. crassa actin-like protein. The first method was essentially as described by Kotelliansky et al. (1979) except that $1 \mu \mathrm{g}$ DNAase I was used and the total assay volume was $10 \mathrm{ml}$. For the second method, DNA-methyl green was used as the substrate for DNAase I. DNA-methyl green was dissolved in $100 \mathrm{~mm}$-Tris, $4 \mathrm{~mm}-\mathrm{MgCl}_{2}, 1.7 \mathrm{~mm}-\mathrm{CaCl}_{2}$, pH 7.5 to a final concentration of $0.25 \mathrm{mg} \mathrm{m}^{-1}$ and was stored at $4{ }^{\circ} \mathrm{C}$ prior to use. DNAase I was dissolved in $0.15 \mathrm{M}-\mathrm{NaCl}$ to a final concentration of $100 \mu \mathrm{g} \mathrm{m} \mathrm{m}^{-1}$ and stored frozen. DNAase I solution $(10 \mu \mathrm{l})$ and up to $0.5 \mathrm{ml}$ of an actin-containing sample were added to cuvettes and incubated at room temperature for $0.5 \mathrm{~h}$. Then $0.3 \mathrm{ml}$ of the DNA-methyl green solution was added and incubation was continued for $8 \mathrm{~h}$. After incubation, each cuvette was brought to $1 \mathrm{ml}$ with $100 \mathrm{mM}$-Tris, $4 \mathrm{mM}-\mathrm{MgCl}_{2}, 1.7 \mathrm{mM}-\mathrm{CaCl}_{2}, \mathrm{pH} 7.5$. A blank containing only DNA-methyl green and a control containing both DNA-methyl green and DNAase I were incubated in parallel with the samples. Inhibition of DNAase I by actin was calculated as follows:

Percentage inhibition of DNAase I $=100 \times\left(A_{630}\right.$ blank $-A_{630}$ sample $) /\left(A_{630}\right.$ blank $-A_{630}$ control $)$

Sodium dodecyl sulphate (SDS)-polyacrylamide gel electrophoresis. This was performed according to O'Farrell (1975) with $12.5 \%$ gels using a stacking gel in a vertical slab gel apparatus $(15 \times 15 \mathrm{~cm})$. Molecular weights assigned to the standard proteins were: bovine serum albumin (68000); actin (42000); DNAase I (31000); myoglobin (18000).

Chemicals. Rabbit skeletal muscle actin was from Worthington. All other reagents were purcilased from Sigma.

\section{RESULTS}

In attempts to determine whether extracts of Neurospora crassa contain an actin-like protein, cultures were processed in one of two ways. Cells were either precipitated with acetone prior to extraction of cellular proteins or used directly in the extraction procedure. No differences in the electrophoretic patterns of proteins were observed between acetoneextracted cells and cells used directly in the homogenization procedures. For this reason, cells for actin isolation were used immediately after harvesting and were extracted as described in Methods. Cells processed in buffers lacking PMSF and benzamidine showed no discernible protein patterns following electrophoresis. Thus, in all subsequent isolation steps PMSF and benzamidine were added to minimize protein degradation. The $N$. crassa cell extracts contained a protein which co-migrated during electrophoresis with rabbit skeletal muscle 


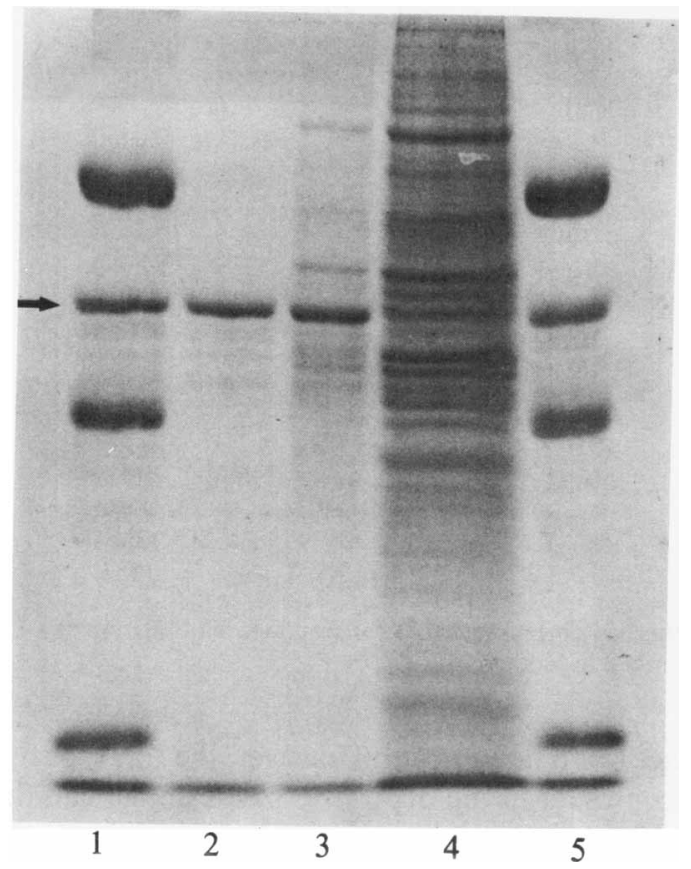

Fig. 1. SDS-poly acrylamide gel electrophoresis of fractions obtained during actin purification. Lanes 1 and 5, protein standards - bovine serum albumin, actin, DNAase and myoglobin (20 $\mu \mathrm{g}$ each protein). Lane $2, N$. crassa protein sample from the DNAase I-Sepharose column (25 $\mu$ g protein). Lane 3, fraction 54 from the DEAE-cellulose column $(25 \mu \mathrm{g}$ protein). Lane 4, total soluble proteins from $N$. crassa mycelium $(125 \mu \mathrm{g}$ protein). The arrow identifies actin.

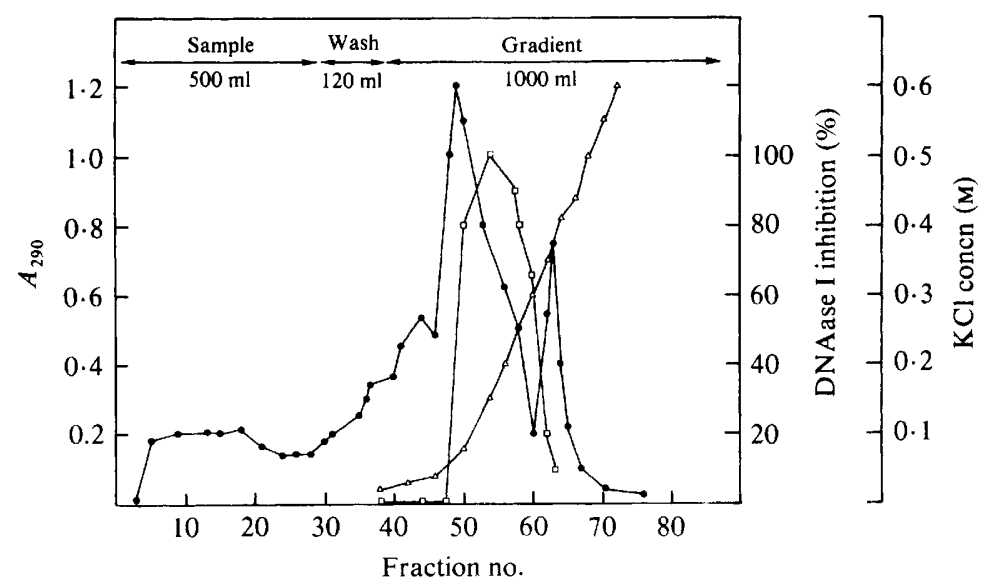

Fig. 2. DEAE-cellulose chromatography of $N$. crassa crude cell extract. The column was eluted as described in the Methods. DNAase I inhibition was determined using the DNA-methyl green assay ( $\square$ ). Elution of protein was monitored by absorbance at $290 \mathrm{~nm}(\mathbf{O})$. Conductivity was used to determine the $\mathrm{KCl}$ concentration $(\triangle)$.

actin (Fig. 1). Furthermore, this protein represented approximately $2 \%$ of the total soluble proteins in cell extracts as judged by densitometric scans of stained polyacrylamide gels.

Efforts to purify actin by repeated rounds of polymerization and depolymerization met with limited success. After one round of polymerization and depolymerization, a protein co-migrating with authentic actin was enriched compared with the amount found in the 


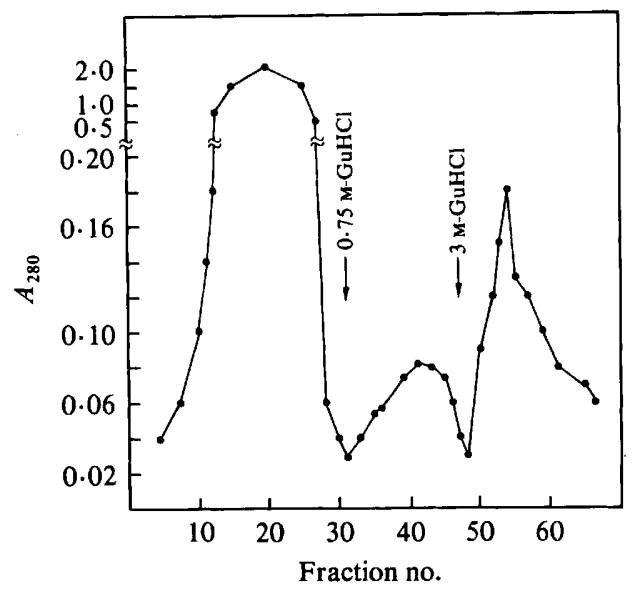

Fig. 3. DNAase I-Sepharose chromatography of fractions 47-63 from the DEAE-cellulose column (Fig. 2). Details are described in Methods.

original whole cell extract (data not shown). However, the total spectrum of proteins found in the cell extract was also present in the depolymerized sample, and the low molecular weight proteins appeared to be present in greater amounts than the higher molecular weight proteins. Following a second round of polymerization, the proportion of proteins co-migrating in gels with authentic actin was very much decreased, but a new band greater in molecular weight than actin was observed. This band most likely represented a dimeric actin form. The extended dialysis necessary to depolymerize $\mathrm{F}$-actin may have resulted in protein degradation and/or incomplete depolymerization, accounting for the loss of the actin-like protein. Similar results were obtained even when PMSF and benzamidine were included in the polymerization and depolymerization buffers.

Ion-exchange chromatography using DEAE-cellulose has proven useful in isolating actin from other organisms (Gordon et al., 1976; Henney \& Izadpanah, 1979; Kotelliansky et al., 1979). When an $N$. crassa cell extract was chromatographed on DEAE-cellulose and eluted with a $\mathrm{KCl}$ gradient, the profile shown in Fig. 2 was obtained. DNAase I-inhibiting activity was found in the latter half of the first large protein peak and consistently eluted between $0 \cdot 10$ and $0.35 \mathrm{M}-\mathrm{KCl}$. When the crude extract was chromatographed on DEAE-cellulose with an entirely different buffer system and eluted with a shallower $\mathrm{KCl}$ gradient (Gordon et al., 1976) the DNAase I-inhibiting activity still eluted within the same $\mathrm{KCl}$ concentration range (data not shown). Furthermore, actin isolated from yeast as a control showed the same elution characteristics (data not shown). The $0 \cdot 10-0.35 \mathrm{M}-\mathrm{KCl}$ eluate inhibited DNAase I in both assays used (see Methods).

A sample of each fraction from the DEAE-cellulose column was assayed for DNAase I inhibition and its protein content was examined by electrophoresis in an SDS-polyacrylamide gel. Fraction 54 (see Fig. 2) inhibited actin to the greatest extent and gel electrophoresis revealed that it contained several proteins, the major one of which co-migrated with skeletal muscle actin (Fig. 1). Densitometric scans of SDS-polyacrylamide gels of this fraction indicated that it contained $30 \%$ actin. Other fractions that inhibited DNAase I also contained this protein. The DNAase I-inhibiting fractions (47-63) from the DEAE-cellulose column were pooled and chromatographed on a DNAase I-Sepharose affinity column. A protein profile of the fractions eluted from the affinity column is shown in Fig. 3. The first GuHCl wash $(0.75 \mathrm{M})$ was ineffective in eluting all of the bound protein from the column and a large amount of protein was eluted in the subsequent $3 \mathrm{M}-\mathrm{GuHCl}$ wash. The DNAase I-Sepharose column had been previously tested with rabbit skeletal muscle actin, which also eluted primarily in the $3 \mathrm{M}-\mathrm{GuHCl}$ wash (data not shown). By integration of the areas beneath each 
Table 1. DNAase I inhibition by fractions from DEAE-cellulose and DNAase I-Sepharose columns

DNAase I inhibition was estimated by the DNA-methyl green assay.

\begin{tabular}{|c|c|c|c|}
\hline Column fraction & $\begin{array}{l}\text { Sample vol. } \\
\text { (ml) }\end{array}$ & $\begin{array}{l}\text { Protein } \\
\quad(\mu g)\end{array}$ & $\begin{array}{c}\text { Inhibition of } \\
\text { DNAase I* } \\
(\%)\end{array}$ \\
\hline $\begin{array}{l}\text { DEAE-cellulose, } \\
\text { fraction } 54\end{array}$ & $\begin{array}{l}0.10 \\
0.50\end{array}$ & $\begin{array}{l}1 \\
5\end{array}$ & $\begin{array}{l}100 \\
100\end{array}$ \\
\hline $\begin{array}{l}\text { DNAase I-Sepharose, } \\
0.75 \mathrm{M}-\mathrm{GuHCl} \text { eluate }\end{array}$ & $\begin{array}{l}0.01 \\
0.10 \\
0.50\end{array}$ & $\begin{array}{l}0 \cdot 1 \\
1 \\
5\end{array}$ & $\begin{array}{r}1 \cdot 2 \\
7 \cdot 2 \\
19 \cdot 1\end{array}$ \\
\hline $\begin{array}{l}\text { DNAase I-Sepharose, } \\
3 \mathrm{M}-\mathrm{GuHCl} \text { eluate }\end{array}$ & $\begin{array}{l}0.01 \\
0.10 \\
0.50\end{array}$ & $\begin{array}{l}0 \cdot 1 \\
1 \\
5\end{array}$ & $\begin{array}{r}3 \cdot 6 \\
11 \cdot 3 \\
25 \cdot 6\end{array}$ \\
\hline
\end{tabular}

\footnotetext{
* Complete inhibition of DNAase I activity occurred when $0.5 \mu \mathrm{g}$ of rabbit skeletal muscle actin was used in the assay procedure.
}

of the protein peaks eluted from the DNAase I affinity column, it was estimated that $5 \%$ of the $N$. crassa protein applied had bound to the affinity column and was eluted with $\mathrm{GuHCl}$ $(0.75 \mathrm{M}$ and $3 \mathrm{M})$. The material eluted from the DNAase I-Sepharose column by $\mathrm{GuHCl}$ was concentrated and examined by SDS-polyacrylamide gel electrophoresis. We could detect only a single major protein band, which co-migrated with authentic actin (Fig. 1). This protein represented at least $80 \%$ of the protein applied to the SDS-polyacrylamide gel.

Table 1 shows DNAase I inhibition results for samples eluted from the DEAE-cellulose and the DNAase I affinity columns. A sample of fraction 54 from the DEAE-cellulose column inhibited DNAase I completely. Comparable amounts of protein eluted from the affinity column by $\mathrm{GuHCl}$ inhibited DNAase I only poorly. Prior experiments utilizing buffers without protease inhibitors suggest that protease degradation may occur during the DNAase I affinity chromatography and the subsequent dialysis. In fact, if the dialysis time was greater than $24 \mathrm{~h}$ and PMSF and benzamidine concentrations were decreased, the major protein species detected by electrophoresis had a molecular weight of only 28000 , indicative of a protease attack upon actin.

In another experiment, $N$. crassa proteins that had undergone one round of polymerization and depolymerization were applied to the DNAase I affinity column. The profile of protein eluting from this column looked identical to that in Fig. 3 except that the $A_{280}$ values were slightly lower. Electrophoresis of the $\mathrm{GuHCl}$-eluted material revealed a faint band co-migrating with authentic actin as well as three to five other bands (data not shown).

\section{DISCUSSION}

The presence of an actin-like protein in extracts of $N$. crassa was previously suggested by Allen \& Sussman (1978): the appearance of negatively stained filaments in extracts of $N$. crassa after incubation with $\mathrm{ATP}, \mathrm{CaCl}_{2}$ and $\mathrm{KCl}$ was similar to actin filaments observed in other systems with the electron microscope. We have now identified a protein that has several properties in common with skeletal muscle actins and non-muscle actins. This protein both in crude cell extracts and in its purified form co-migrates with rabbit skeletal muscle actin. It elutes from DEAE-cellulose under the same ionic conditions as does yeast actin, it undergoes polymerization-depolymerization reactions and it inhibits DNAase I activity, comparable to that achieved with rabbit skeletal muscle actin. The specificity of the DNAase I interaction with actin has itself been the basis of actin purification schemes (Dhermy et al., 1978; Lazarides \& Lindberg, 1974) and has become a major criterion in establishing a protein as 
actin. We have examined in parallel $N$. crassa and yeast actin using the DEAE-cellulose chromatographic method of Gordon et al. (1976). In each instance, the protein profile, the DNAase I-inhibiting activity and the electrophoretic pattern of proteins were identical. When the appropriate $N$. crassa fractions from the DEAE-cellulose column were further chromatographed on DNAase I-Sepharose, a single protein was eluted by $\mathrm{GuHCl}$ and it co-migrated with rabbit skeletal muscle actin.

Polymerization and depolymerization was not effective in purifying $N$. crassa actin. One round of polymerization and depolymerization produced a preparation enriched for actin but seriously contaminated with other proteins (not shown). A second round of polymerization resulted in losses of large amounts of protein, possibly due to an ineffective polymerization or inadequate depolymerization. Similar results have been observed in other systems (Henney \& Izadpanah, 1979; Reichstein \& Korn, 1979).

The identification of actin as an abundant protein in $N$. crassa is not surprising in view of its presumed functions in eukaryotic organisms. Assuming that rabbit skeletal muscle actin and $N$. crassa actin inhibit DNAase I activity equally, we estimate that actin comprises $1-2 \%$ of $N$. crassa soluble proteins. This figure agrees well with results of densitometric scans of the SDS-polyacrylamide gels containing total $N$. crassa soluble proteins. In Dictyostelium discoideum, actin normally comprises $8 \%$ of cellular proteins and can increase to $25 \%$ in differentiating cells (Alton \& Lodish, 1977). In the experiments reported here, we isolated actin from $N$. crassa cells grown for $18-20 \mathrm{~h}$, when they were in exponential, vegetative growth. It is possible that in other developmental stages, such as early conidial formation or during spore germination, actin may occur in greater amounts.

Actin eluted from the DNAase I affinity column inhibited DNAase I poorly. Poor DNAase I inhibition by actin after its elution from a DNAase I column has been reported by Henney \& Izadpanah (1979). Denaturation of the actin most likely occurred due to the $\mathrm{GuHCl}$ used for its elution from the affinity column. We did not recover large amounts of actin from the DNAase I affinity column in the absence of protease inhibitors. Attempts to isolate actin from $N$. crassa mycelium were unsuccessful unless PMSF and benzamidine were added to all buffers employed in the isolation. Moreover, when the protease inhibitors were not added to the eluant of the DNAase I affinity column no actin was detected, but we found instead a single protein band of increased mobility (mol. wt 28000), indicating proteolysis. The presence of an altered actin band of defined molecular weight may mean that protease attack is at least initially confined to a specific region of the actin molecule. The generation of actin-like artifacts by possible proteolytic attack on the actin molecule has been discussed by Water et al. (1980). Protease problems with $N$. crassa extracts have been recognized by other workers (Gaetner \& Cole, 1976, 1977). The 'snowflake' mutant of $N$. crassa appears to contain abnormally large amounts of actin-like protein (Allen \& Sussman, 1978). Future studies with this mutant may provide valuable insights into the regulation of the actin gene and the synthesis of the actin protein.

This research was supported by grant GM-23367 from the National Institutes of Health and grant PCM 78-16021 from the National Science Foundation.

\section{REFERENCES}

Allen, E. D. \& Sussman, A. S. (1978). Presence of an actin-like protein in mycelia of Neurospora crassa. Journal of Bacteriology 135, 713-716.

Alton, T. A. \& Lodish, H. F. (1977). Developmental changes in mRNA's and protein synthesis in Dictyostelium discoideum. Developmental Biology 60, 180-206.

Bender, W., Davidson, N., Kindle, K. L.. TAYlor, W. C., Silverman, M. \& Firtel, R. A. (1978). The structure of M6, a recombinant plasmid containing Dictyostelium DNA homologous to actin messenger RNA. Cell 15, 779-788.

Dhermy, D., Bournier, O. \& Boivin, P. (1978). Partially polymerized erythrocyte actin obtained by affinity chromatography on DNase Sepharose. Comparison with rabbit skeletal muscle actin and role of calcium. Biochemical and Biophysical Research Communications 85, 906-915. 
Gaetner, F. H. \& Cole, K. W. (1976). The protease problem in Neurospora: structural modification of the arom multienzyme system during its extraction and isolation. Archives of Biochemistry and Biophysics 177, 566-573.

Gaetner, F. H. \& Cole, K. W. (1977). A cluster gene. Evidence for one gene, one polypeptide, five enzymes. Biochemical and Biophysical Research Communications 75, 259-264.

Gordon, D. J., Eisenberg, E. \& Korn, E. D. (1976). Characterization of cytoplasmic actin isolated from Acanthamoeba castellanii by a new method. Journal of Biological Chemistry 251, 4778-4786.

Hatano, S. \& Oosawa, F. (1966). Isolation and characterization of plasmodia actin. Biochimica et biophysica acta $127,488-498$.

Henney, H. R. \& Izadpanah, M. (1979). Purification of actin and a 51,000 dalton protein from haploid cells of Physarum flavicomum. Experimental Mycology 3, 310-320.

KINDLE, K. L. \& FIRTEL, R. A. (1978). Identification and analysis of Dictyostelium actin genes, a family of moderately repeated genes. Cell 15, 763-778.

KORN, E. D. (1978). Biochemistry of actomysindependent cell motility. Proceedings of the National Academy of Sciences of the United States of America 75, 588-599.

Kotelliansky, V. E., Glukova, M. A., Benjanian, M. V., Surguchov, A. P. \& Smirnov, V. N. (1979). Isolation and characterization of an actin-like protein from yeast Saccharomyces cerevisiae. FEBS Letters 102, 55-58.

LAZARIDES, E. \& LiNDBERG, U. (1974). Actin is the naturally occurring inhibitor of deoxyribonuclease I. Proceedings of the National Academy of Sciences of the United States of America 71, 4742-4746.

Margolskee, J. P. \& Lodish, H. F. (1980). The regulation of the synthesis of actin and two other proteins early in Dictyostelium discoideum development. Developmental Biology 74, 50-64.
MCKeown, M., TAYloR, W. C., KINDLE, K. L., FirTel, R. A., Bender, W. \& Davidson, N. (1978). Multiple heterogeneous actin genes in Dictyostelium. Cell 15, 789-800.

Munkres, K. D. (1962). A method for the preparation of mycelial acetone powder of Neurospora. Neurospora Newsletter 1, 12.

O'FARrell, P. (1975). High resolution twodimensional electrophoresis of proteins. Journal of Biological Chemistry 250, 4007-4021.

Pollard, T. D. \& Weihing, R. R. (1974). Actin and myosin and cell movement. CRC Critical Reviews in Biochemistry 2, 1-65.

Reichstein, E. \& KORN, E. D. (1979). Acanthamoeba profilin, a protein of low molecular weight from Acanthamoeba castellanii that inhibits actin nucleation. Journal of Biological Chemistry 254, 6174-6179.

Spudich, J. A. (1974). Biochemical and structural studies of actinomyosin like properties and membrane association of actin from Dictyostelium discoideum. Journal of Biological Chemistry 249, 6013-6020.

Spudich, J. A. \& WATT, S. (1971). The regulation of rabbit skeletal muscle contraction I. Biochemical studies of the interaction of the tropomyosintroponin complex with actin and the proteolytic fragments of myosin. Journal of Biological Chemistry 246, 4866-4871.

Uyemura, D. G., Brown, S. S. \& Spudich, J. A. (1978). Biochemical and structural characterization of actin from Dictyostelium discoideum. Journal of Biological Chemistry 253, 9088-9096.

Vogel, H. J. (1956). A convenient growth medium for Neurospora (medium N). Microbial Genetics Bulletin 13, 42-43.

Water, R. D., Pringle, J. R. \& Kleinsmith, L. J. (1980). Identification of an actin-like protein and of its messenger ribonucleic acid in Saccharomyces cerevisiae. Journal of Bacteriology 144, 1143-1151. 